\title{
Impact of Digital Growth in Modern Business
}

\author{
Zoran Mastilo \\ Correspondence: Zoran Mastilo, Faculty of Business Economics in Bijeljina, University of East Sarajevo, Bijeljina, \\ Bosnia and Herzegovina.
}

Received: September 13, 2017

Accepted: November 8, 2017

Online Published: November 12, 2017

doi:10.11114/bms.v3i4.2650

URL: https://doi.org/10.11114/bms.v3i4.2650

\begin{abstract}
Target research in this paper is the assessment and analysis of content of digital progress and its impact on modern business. Business digitization has been introducing increasingly dynamic changes across the entire global economic sphere, whereas its content increasingly maintains to affect the competitiveness of national economies. At the microeconomic level, digital technologies lead to a change of economic structure and quality of production factors, based on knowledge and innovations. This paper should provide specific answers on how to apply new technologies and digital techniques in a quality manner within the knowledge economy. This is not the only answer provided in this paper. On the contrary, the paper shall respond to question how to minimize the risks of all kinds, in order to increase labour productivity. The immediate objective of this paper is to adequately locate and understand the problem of economy digitization and the changes it brings, as well as to provide specific ideas and practical solutions for better and more efficient business operations. The new information, i.e. digital economy fundamentally differs from the traditional ones. This very synergy of workforce, its emergence in such manner, as well as increase in its presence, will be the biggest challenge to what we now call the digital economy. The IT revolution and communication technology affect the development of the new economy on a global scale, which significantly contributes to the modern business. The impact of digital growth on modern business should be reflected in increased productivity, knowing that the increase in productivity is a key issue in any economy, including the digital economy. Increasing productivity implies an increase in the results achieved with the same consumption of resources or achieving the same results with less consumption of resources. Numerous studies have been performed on this subject at the global level, demonstrating that there are serious analyses and research that show exactly how much the investment in IT does actually increase productivity. It is believed that the majority of the growth in productivity since 1995 to date is to be primarily credited to investments in information technology and business process automation. Increasing productivity is evident almost anywhere: in individual companies, industries and economies, which actually represents the essence of modern business activities.
\end{abstract}

Keywords: innovations, knowledge, digital economy, information technology, growth and productivity, communication technologies, concurrency

\section{Introduction}

Digital economy is based on information technology. It poses as a new form of economy, which certainly should represent one of the most attractive growth opportunities. The development of digital technology today is valued as something that is expected, which is why digital technologies enter into our private lives and business activities in order to enable us to perform business activities in the best manner possible. Innovations in the field of information technology, computer networks, telecommunications and transport systems contributed to the linking of market at all distances and an unprecedented boom in the international movement of capital, goods, services, people, ideas and cultural values. In such conditions, the economy is referred to as weightless, information, network, digital, technotron, E-conomy, etc., all of which, in the opinion of many authors, generates the term "new economy". The level of technological changes that characterize today's global economy and the ever-increasing utilization of IT has led to changes in the economic environment, forcing the business systems to execute changes. Traditional forms of business take on new shapes and forms, whereas a large part of the business is transferred to the internet, where it continues being executed, but electronically, using all the advantages provided by the network and new web technologies. Thus, the operating systems have taken advantage of new features such as continuity in the implementation of business processes and adding value to products and services offered, thus providing increased productivity, creating new business values and implementation of specific positions in the market. Digital economy has four key impacts on today's global economy. It creates a brand new content or use-value of products and services that did not exist before. 
Secondly, there is the destructive impact of digital aspects of modern business, which threatens traditional business models, imposing new business rules. An important impact of the digital economy, functioning as the improvement of existing business content is in symbiosis with the traditional business and fully acts upon their growth and development. Another new feature that is indispensable concerns a completely new way of communication among the people, based on principle of everyday communication by utilizing all the applications provided by the IT. Finally, it is a chance for new jobs. In the US alone in the past five years, 500000 new jobs have been opened, while Bosnia and Herzegovina is severely lagging behind.

\section{Information and Communication Technologies and Modern Business}

The concept of digital economy combines investment and technological development, on one hand and economic growth on the other. Relationship between the amount, intensity and dynamics in which one influences or causes the other should be recognized, which actually represents the greatest challenge for those involved in economic development projections. Today's information and communication technologies (ICT) are constantly progressing and their application in the business world has left a mark on modern business in recent history. Constant digital growth contributes to the convergence of traditional forms of international business operations, on one hand, and information technology, on the other. More and more of participants in the business world is trying to take advantage of digital technologies; many businesses are considered to be underdeveloped in digital terms, which limit them in the direction of modern business activities. Research shows that the digital economy, which includes digital arts and digital capital, represents more than $22 \%$ of the global modern business. Thus, it is evident that digital options and their impact on modern business have not been sufficiently utilized. Therefore, the business world has to be engaged faster on the matter. The enormous changes that have emerged in the business world have sent a signal to technology companies, the key signal being that a user should be in the centre of their interests and that they should adapt and conform to its requirements, reminding on those who adapted slowly and therefore entered the zone of loss, but also on those who were more open and thus increased the number of their customers. Considering all the processes that take place in this area, it is necessary to understand the method on how investing in what makes the digital economy affects the GDP growth and the extent to which such occurrence takes place. A study published by Oxford Economics in January 2016 predicts that the development of the digital economy by 2020 would contribute to the economic growth of $25 \%$, if this area would be properly backed up by investments. The volume of digital growth and its impact on modern business is greater than can be seen from today's perspective, by anyone who is not devoted to a detailed analysis of all its segments. It should be noted that large companies, in their search for the possibility of business diversification, have recognized ICT as a factor to raise competitiveness. Governments and managements of multinational companies in developed countries are trying to encourage the development of innovative activities in electronics and communications (Ćuzović et al. 2014).

The above should contribute to a more productive business (activities) of the business community. This is not possible without innovation which should be in the function of e-infrastructure.

The competent national authority for research infrastructure should identify priority areas which will be prioritized for development in the upcoming periods, taking into account the principle of national and socially responsible funding.

Principles for the establishment and strengthening of national e-infrastructure are based on the following:

1. strategic embeddedness and compliance with national strategic documents and compliance with European strategic guidelines, ESFRI and ERIC compatibility;.

2. scientific potential, which requires: studying the basic purpose of the infrastructure, overview of the number of researchers with significant research potential, prediction of the expected scientific findings using the infrastructure, i.e. the importance of infrastructure for innovative processes. It is important to assess whether a single e-infrastructure has been planned in the country, or if there are similar infrastructures being planned, are there clear indicators of the current scientific and professional productivity? For modern business based on encouraging innovation of e-infrastructure, the method of utilization and the size of the availability of the customer base are of great importance, as well as which groups can access the infrastructure.

By accepting the initiative and the EU's agenda relating to the development of information society in the countries of South Eastern Europe, the Western Balkans countries have adopted their own national strategies, which include recommended priorities and guidelines for the development of the information society. The basis for the construction of these national strategies is still founded upon own resources of the Western Balkan countries (G. Đorđević).

It is necessary to establish priorities (with the most relevant method being - through a strategy) which relate to the following areas:

- electronic communications 
- e-government, e-health, e-justice,

- ICT in education, science and culture,

- e-commerce, business sector and information security.

We are faced with differences of the countries development level, social groups and individuals, which is in direct proportion to the difference in the level of application of the ICT. No society should allow to be excluded or brought to a margin. Countries and their governments must act quickly in the direction of reducing the differences in technological development (in relation to the world and Europe), because the process of transition from an industrial to an information society in developed countries is at an advanced stage. The digital gap, as the difference between the application of ICT and e-business exists not only between developed countries and countries in transition, but also on routes such as urban and rural environments, and large and small companies (G. Đorđević).

\section{The New Economic Order and Contemporary Business}

The influence of digital economy on the modern business activities manifests itself/is manifested in four types, considering the fact that the term "digital economy" appeared in the Don Tapscott's book of the same name. This is considered to be a revolutionary idea that transformed itself into the present economic form which infiltrates every economic and social process and which needs to be talked about, written about and considered from multiple points of view. The development of economy causes significant changes that due to that fact occur in demand and supply.

One of the announced said influences is seen as a relationship between traditional and digital economies. Digital strategists agree upon the fact that the digital economy has the key impact on the modern business activities by creating entirely new content or usability of products and services that didn't exist before.

There is a destructive influence of digital aspects of contemporary/modern business activities that endangers the traditional business models by imposing new business rules.

The next big influence of digital economy, which functions as an improvement of already existing contents, is in a symbiotic relationship with the traditional business activities and complementarily affects their growth and development.

A very important innovation is about the new way in which people communicate with each other. The rapid development of the information, as well as the (tele) communication technologies, which the infrastructure of digital economy is essentially based upon, has largely/greatly transformed the way of everyday communication.

According to the data of the European Commission, thanks to the dynamic development of mobile digital applications' marketplace, the USA has, in the past five years, created approximately 500000 new job vacancies/workplaces/job openings. In that aspect, Europe is still lagging behind with development and creative implementation of the new technologies in its market. We estimate that, if the EU countries could achieve the level of technological and digital development America has achieved, during the following period, it could make creating up to one and a half million of new, so called "digital" workplaces/jobs in Europe possible. In that aspect, Bosnia and Herzegovina and the neighbouring countries are far behind the most developed countries.

\section{Paradigmaticness of the New Economy}

The entire socio-economic structure created by ever growing influence of the information and communication technologies (ICT) over every aspect of human life is called the information society (IS). In (reference) books, the modern business activities developed under the influence of said technology within the (IS) are defined as (new economy). The term "new economy" has been used since the end of 1990s to explain a range of new economic, social and cultural changes prompted by the development of information technology. Usually, this term is used to describe everything about IT, that is, with the appearance and the use of internet. The new economy (NE) as an economic segment of so called information society is created as a result of two contemporary processes happening simultaneously. On the one hand, (NE) as the new economic system is formed, first of all, as a result of technological revolution which is mostly based on IT whose use on a micro-level (the change of business models and types of workplaces in companies, that is, the change of the whole business environment) affects the macroeconomic occurrences and processes, and, thereby, affects the economy as a whole. At the beginning of XXI century, the economic performance of developed countries was significantly dependent on the level of diffusion and usage of IT, as well as the achieved degree of development of the new economy and information society. The use of IT, besides the positive effects on the economic growth and development of a country, also has some negative consequences mostly presented in the form of digital division.

One of the most significant questions in economic theory is whether (or not) investing in IT increases labour productivity and accelerates economic growth. Contribution of information and communication technology to the 
economic growth varies considerably among the countries. Investing in information goods and services may increase a country's economic growth in various ways.

First of such ways would be the production of IT goods and services that directly contribute to the total added value produced in a country. Second, as an input to the production of other goods and services via the use of IT. The third one, through the influence of IT industry onto multifactor productivity, i.e. the impact of IT industry onto efficiency and productivity in other sectors that do not fall within the IT domain. Given that the production of information goods requires the use of technological production processes, management of such production activities can result in increase of labor productivity much more than in other economic sectors. Therefore, the increase percentage of IT production in overall economic output may increase the overall level of productivity of a country (R. M. Albers, 2006).

Most authors who have studied macroeconomis consequences of the introduction and application of information technology mainly paid attention to changes in labor productivity. Allocation of the potential benefits created by information technology is not significantly addressed in the available literature. Entities that benefit from technological progress are the owners of capital (in the form of higher profit rates), employees (in the form of higher working fees) and end products buyers (through lower prices). Renowned economist V. Drašković believes that the "new economy" is creating a new paradigm in strategic management (V. Drašković 2003, p. 30) and the need for paradigmatic change of mindsets and economic behaviour. From the perspective of the new paradigm, it seems to us that the new economy deserves such label only in terms of new economic realities, economic skills, the new nature of the company, its structure and organization (V. Drašković). Appreciating the above, we are in a dilemma whether to support G. Kolodko, who says that "despite new technologies and forms of economic activity, the old laws, described by the traditional economic science, starting from the eternal law of supply and demand"(2002), still apply.

\subsection{Virtual Jobs}

In recent years there has been a significant increase of the number of virtual jobs in developed countries. The US company CBI / Pertemps declared that $46 \%$ of employers offers a virtual recruitment since 2008 , whereas only $14 \%$ of employrs did so only two years before. Bosnia and Herzegovina and its business environment should follow this trend of opening virtual jobs, as it would provide great benefit and contribute to the contemporary business operations. The benefit is twofold: speaking from the perspective of an individual - job security and establishment of a proper balance between private and professional life, whereas the economy would benefit the most from increase of productivity at lower cost.

Virtual task execution is a solution organized in such manner where some or all employees work outside of conventional office using the IT package of information technologies which enables them to successfully complete their work obligations. Both employees and the employers benefit from such work method. The most common professions are technicians / professionals, salesmen, clerks / administrative staff, managers. On one side, there are highly educated, experienced, full-time employed professionals who do their work from home during regular working hours. On the other, there are part-time workers with many years of experience which by using a computer, perform administrative and professional tasks from home, outside normal working hours (K. Luyt, 2007).

Virtual workplaces have their own advantages and disadvantages, which will be discussed in a more detailed and dedicated version of this topic.

\section{Conclusion}

Numerous experiences show that in the knowledge-driven economies there is a spread of development opportunities, as well as change of business conditions of their economic entities. Knowledge-based business utilizes knowledge in all of its operations and activities. Research shows that the most developed countries are the ones that have initiated process of managing their intellectual capital in a timely manner, which led to acceleration of their economic development. Modern business cannot achieve a satisfactory business success without proper knowledge. This is illustrated by the fact that the most propulsive branches of economy are the ones that base their business and development upon knowledge. Based on the structure of employment, treatment of knowledge and the amount of investment in this area, business in $\mathrm{BiH}$ cannot be included in the group of knowledge-based businesses. However, it can be said that there are unused human resources in the domestic economy, as evidenced by the structure of the unemployed. Unemployment in the Republic of Srpska is high and particularly evident in the high percentage of highly educated young people, which is devastating for our society. This is an indicator of an inadequate treatment of young, educated people and unused human potential, which certainly has a negative impact on business. The legal path of development of the $\mathrm{BiH}$ economy is to direct the economy towards the development of those industries that are propulsive and that bring higher profits. Investment in knowledge and skills is investment in the future, and is by no means an unwelcome expense of business entities and the state. 
The development of knowledge-based economy would reduce the brain drain from less developed countries. An adequate educational system, as well as adequate investments in research and development would, in the long run, substantially contribute to solving the current economic problems that are related to modern business.

Therefore, knowledge and highly educated young people with innovative skills will contribute to a more competitive modern business (activities) in $\mathrm{BiH}$, which is the basic need of every society.

Higher productivity and virtual jobs are actually measurable effects for modern business.

\section{Reference}

Albers, R. M. (2006). From James Watt to Wired Networks: Technology and Productivity in the Long Run in Mas, M. and P. Schreyer (ed.). Growth, Capital and New Technologies, Bilbao: Fundacion BBVA,

Ćuzović, Đ., \& Sokolov, M. S. Globalization and the Digital Economy (orig. Globalizacija i digitalna ekonomija); Novi Sad Business School, Serbia, Faculty of Economics, Niš, Serbia.

Đorđević, G. Impacts of ICT Information Society on the socio-economic development, (orig. Uticaji ICT Informacionog društva na društveno ekonomski-razvoj original scientific article UDK: 681 518: 33034 JEL: D83, F63; Alfa University, Belgrade Faculty of Trade and Banking.

Drašković, V. (2005). Paradigmatičnost nove ekonomije (eng. Paradigmaticness of the new economy), Montenegrin Journal of Economics, 1(1), Montenegro. http://www.mnje.com/sites/mnje.com/files/dra_kovi.pdf

European Commission. (2004). Innovation Management and the Knowledge-Driven Economy, ECSC-EC-EAEC, Brussels - Luxemburg.

Kolodko, G. (2002). New Economics and Stary problem (orig.), Problems in the theory and practice management, 3. (orig. “Новая экономика и старые проблемы”, Проблемы теории и практики управления Но 3 ).

Luyt, K. (2007). Mindsets Required for Implementing a Virtual Workplace, Doctoral Dissertation, Gordon Institute of Business Science, University of Pretoria.

\section{Copyrights}

Copyright for this article is retained by the author(s), with first publication rights granted to the journal.

This is an open-access article distributed under the terms and conditions of the Creative Commons Attribution license which permits unrestricted use, distribution, and reproduction in any medium, provided the original work is properly cited. 